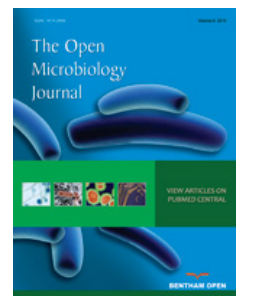

\title{
CORRIGENDUM
}

\section{Non-Antimicrobial Drugs: Etodolac as a Possible Antimicrobial or Adjuvant Agent Against ESKAPE Pathogens}

Sónia G. Pereira ${ }^{1, *}$, Vanessa S. Domingues ${ }^{2}$, João Theriága ${ }^{1}$, Maria de Jesus Chasqueira ${ }^{1}$ and Paulo Paixão ${ }^{1}$

${ }^{I}$ CEDOC-Chronic Diseases Research Center, NOVA Medical School, NOVA University, Lisboa, Portugal

${ }^{2}$ Faculty of Pharmacy, University of Coimbra, Coimbra, Portugal

Non-Antimicrobial Drugs: Etodolac as a Possible Antimicrobial or Adjuvant Agent Against ESKAPE Pathogens The Open Microbiology Journal, 2018, 12: 288-296

The correct numbering of author 's affiliation is mentioned below:

Sónia G. Pereira ${ }^{1}$, *, Vanessa S. Domingues ${ }^{2}$, João Theriága $^{1}$, Maria de Jesus Chasqueira ${ }^{1}$, Paulo Paixão ${ }^{1}$ The original numbering of author 's affiliation provided was:

Sónia G. Pereira ${ }^{1}, *$, Vanessa S. Domingues ${ }^{2}$, João Theriága $^{2}$, Maria de Jesus Chasqueira ${ }^{2}$, Paulo Paixão

\section{(C) 2018 Pereira et al.}

This is an open access article distributed under the terms of the Creative Commons Attribution 4.0 International Public License (CC-BY 4.0), a copy of which is available at: (https://creativecommons.org/licenses/by/4.0/legalcode). This license permits unrestricted use, distribution, and reproduction in any medium, provided the original author and source are credited. 